\title{
Yayasan Minasa: Tempat Penampungan Eks DI/TII 1969-2018
}

\author{
Astuti Buhari ${ }^{1}$, Muh. Rasyid Ridha ${ }^{2}$, Ahmadin $^{3}$ \\ ${ }^{1}$ Prodi Pendidikan Sejarah Fakultas Ilmu Sosial Universitas Negeri Makassar, Indonesia \\ Email: astutibuhari08@gmail.com
}

\begin{abstract}
Abstrak
Penelitian ini bertujuan untuk mengetahui tentang Yayasan Minasa sebagai wadah penampungan eks DI/TII di Kabupaten Luwu 1969-2018) dengan mengungkap latar belakang berdirinya Yayasan Minasa dan perkembangan Yayasan Minasa dalam bidang sosial ekonomi, pendidikan, dan keagamaan. Hasil penelitian menunjukan bahwa latar belakang didirikannya Yayasan Minasa adalah sebagai imbalan jasa kepada Abdul Aziz Abdullah karena bertindak untuk mengamankan Eks DI/TII yang tersebar di Sulawesi Selatan Tenggara dan mengajak mereka untuk bergabung dengan NKRI. Tujuan utama didirikannya Yayasan Minasa adalah untuk menampung anggota-anggota Ex DI/TII. Dalam perkembangannya selama kurang lebih 49 tahun Yayasan Minasa telah dipimpin oleh dua ketua yaitu Abdul Aziz Abdulllah yang memimpin dari tahun 1969-1999, dan St. Hadeyang yang memimpin dari tahun 2002sekarang. Berdasarkan hasil penelitian maka dapat disimpulkan bahwa yayasan Minasa telah mengalami beberapa perubahan dalam bidang kehidupan sosial ekonomi, bidang pendidikan dan bidang keagamaan dalam kehidupan masyarakat masyarakat.Penelitian ini menggunakan metodologi penelitian sejarah yang meliputi heuristik yaitu tahapan pengumpulan data, kritik sumber bertujuan menilai dan menentukan sumber, interpretasi yaitu menafsirkan data dan tahap historiografi atau penyajian atau penulisan sejarah. Metode pengumpulan data dilakukan dengan cara penelitian lapangan terdiri dari wawancara (Eks DI/TII dan masyarakat Yayasan Minasa) dan mengumpulkan sumber arsip (arsip Yayasan Minasa) serta literatur-literatur yang berhubungan dengan penelitian ini.
\end{abstract}

Kata kunci: Eks DI/TII, Yayasan dan Minasa

\begin{abstract}
This study aims to find out about the Minasa Foundation as a former DI/TII shelter in Luwu Regency 1969-2018) by revealing the background of the founding of the Minasa Foundation and the development of the Minasa Foundation in the socio-economic, educational, and religious fields. The results showed that the background for the establishment of the Minasa Foundation was in return for services to Abdul Aziz Abdullah for acting to secure the former DI/TII spread across Southeast Sulawesi and to invite them to join the Unitary Republic of Indonesia. The main purpose of establishing the Minasa Foundation was to accommodate Ex DI/TII members. In its development for approximately 49 years the Minasa Foundation has been led by two chairmen, Abdul Aziz Abdulllah, who led from 1969-1999, and St. Hadeyang was in charge from 2002 to present. Based on the results of the study it can be concluded that the Minasa foundation has undergone several changes in the field of socio-economic life, education and religious fields in the life of the community. This research uses historical research methodologies which include heuristics namely the stages of data collection, source criticism aimed at assessing and determining sources, interpretation, namely interpreting data and historiographic stages or presenting or writing history. The data collection method was carried out by means of field research consisting of interviews (former DI/TII and the Minasa Foundation community) and collecting archival sources (Minasa Foundation archives) as well as the literature relating to this research.
\end{abstract}

Keyword: Eks DI/TII, Yayasan dan Minasa

\section{A. Pendahuluan}

Dalam perjalanan panjang sejarah Indonesia keberadaan suatu yayasan telah 
ada sejak dahulu dimana pada saat itu yayasan yang lebih diidentikan dengan organisasi masyarakat yang sudah ada sebelum Indonesia merdeka. Yayasan adalah badan hukum yang terdiri atas kekayaan yang dipisahkan dan diperuntukkan untuk mencapai tujuan tertentu di bidang sosial, keagamaan, dan kemanusiaan, yang tidak mempunyai anggota. (supranomo, 2008). Yayasan yang tumbuh dan berkembang di Indonesia bersumber pada hukum adat, hukum Islam dan hukum Belanda. Sejak zaman Hindia Belanda bentuk yayasan merupakan suatu bentuk badan hukum yang banyak dimanfaatkan oleh masyarakat zaman Hindia Belanda yang dikenal dengan sebutan "stiching.

Pada masa Orde Lama pemerintah sudah mulai membuat peraturan tentang keberadaan yayasan di Indonesia, namun, belum ada peraturan khusus yang mengatur tentang yayasan. Masa Orde Baru ada banyak yayasan yang didirikan oleh Presiden Soeharto. Menurut Presiden Soeharto yayasan-yayasan itu didirikan karena masih ada hubungannya dengan tugas Presiden/mandataris, yakni menggerakkan kemampuan pemerintah dan kemampuan masyarakat. (Borahima, 2010). Yayasan pada masa Orde Baru belum ada undang-undang yang mengatur khusus tentang yayasan. (Prasetya, 2014)

Di Sulawesi Selatan tepatnya di Kabupaten Luwu juga terdapat yayasan yang pendiriannya dilatar belakangi oleh Gerakan DI/TII. Kabupaten Luwu yang merupakan salah satu daerah yang terkena dampak Gerakan DI/TII yang dipimpin oleh Kahar Mudzakkar. Setelah pemerintah menyatakan bahwa pemberotakan DI/TII telah berakhir ditandai dengan munculnya kabar bahwa tertembak matinya Kahar Muzakkar pada tanggal 3 Februari 1965 bukan berarti bahwa permasalahan yang ditimbulkan oleh gerakan DI/TII telah selesai. Masalah yang kembali muncul adalah bagaimana cara untuk menata kembali kehidupan para eks DI/TII pasca tertembaknya Kahar Muzakkar.
Salah satu bukti sejarah yang dapat dilihat dalam upaya mengembalikan eks DI/TII ini kembali bergabung dengan NKRI yaitu dengan pendirian Yayasan Minasa sebagai bentuk terimakasih pemerintah kepada Abdul Aziz Abdullah yang pada saat itu menjadi salah satu orang yang berpengaruh bagi para eks DI/TII yang tersebar ke beberapa daerah dan bersembunyi di dalam hutan pasca meninggalnya Kahar Mudzakkar. Setelah yayasan ini didirikan maka para eks DI/TII dikumpulkan di yayasan tersebut. Para eks DI/TII yang tinggal di kompleks Yayasan Minasa tidak serta merta meninggalkan nilai-nilai dan kebiasaan-kebiasaan yang telah ditanamkan oleh Kahar Mudzzakkar semasa hidupnya. Justru mereka memilih untuk tetap mempertahankan apa yang sering mereka lakukan semasa pemimpin mereka masih hidup.

Yayasan Minasa memiliki ciri khas berbeda dengan yayasan-yayasan lain yang ada di Indonesia karena Yayasan Minasa berkaitan erat dengan aktivitas para eks anggota DI/TII sehingga menarik untuk diteliti lebih lanjut. Gerakan DI/TII yang telah memunculkan berbagai macam konflik didaerah Sulawesi Selatan. Hal inilah kemudian yang menarik dikaji oleh penulis untuk membahas lebih dalam tentang Yayasan Minasa dan bagaimana kehidupan para eks DI/TII setelah bergabung dengan NKRI.

\section{B. Metode Penelitian}

Setiap penelitian adalah deksripsi secara cermat dan didasarkan atas teori dan metode. Secara umum metode dianggap sebagai cara-cara strategis untuk memamhami realistas, langkah-langkah sistematis untuk memecahkan rangkaian sebab akibat berikutnya. Penelitian, dari kata dasar "teliti" didenifisikan sebagai kegiatan pengumpulan dan pengolahan data yang disajikan secara sistematis dan objektif. (Kutha Ratna, 2010)

\section{Heuristik}

Heuristik berasal dari bahasa Yunani "Heuristiken" yang berarti menemukan 
atau mengumpulkan sumber. Menemukan dan mengumpulkan data dalam kaitannya dengan ilmu sejarah ialah sumber sejarah yang berupa catatan, kesaksian, dan faktafakta lain yang dapat memberikan informasi atau gambaran tentang sebuah peristiwa yang menyangkut kehidupan manusia. (Dien, Madjid, 2014). Adapun sumbersumber sejarah dibedakan menjadi tiga kategori, yang pertama yaitu sumber kebendaaan atau material yang berupa sumber tertulis (dokumen, arsip,surat, catatan harian, foto dan file), dan sumber benda.yang kedua adalah sumber non kebendaan atau immaterial yang dapat berupa kepecayaan, dan yang ketiga adalah sumber lisan. Sumber lisan dapat berupa wawancara. Dalam proses pengumpulan data cara yang dapat dilakukan adalah teknik wawancara.

Dalam metode heuristik ada beberapa teknik yang dapat dilakukan yaitu.

\section{a. Penelitian Lapangan.}

Penelitian lapangan lapangan dilakukan dengan cara wawancara dan observasi. Metode wawancara dilakukan dengan cara melakukan wawancara kepada masyarakat Yayasan Minasa, eks DI/TII, dan penguru Yayasan Minasa. Metode observasi yang dilakukan dengan cara melakukan pengamatan langsung terhadap lokasi yang diteliti. Dalam penelitian ini observasi dilakukan di Yayasan Minasa yang ada di Kabupaten Luwu.

\section{b. Penelitian Pustaka.}

Penelitian pustaka yang dilakukan terkait dengan sumber-sumber tertulis seperti naskah, buku, dan jurnal. Dalam penelitian ini penelusuran sumber buku dan karya ilmiah yang berkaitan dengan yayasan dan Gerakan DI/TII dilakukan di Perpustakaan Jurusan Pendidikan Sejarah, Perpustakaan Umum Universitas Negeri Makassar, Perpustakaan Universitas Hasanuddin, dan Perpustakaan Daerah Kabupaten Luwu . Kemudian studi kearsipan yang biasanya berupa lembaranlembaran seperti surat dan pemberitahuan yang dilakukan di Dinas Perpustakaan dan
Arsip Provinsi Sulawesi Selatan dan arsip pribadi yang dimiliki Yayasan Minasa.

\section{c. Dokumentasi}

Dokumentasi merupakan catatan peristiwa yang sudah berlalu. Dokumen bisa berbentuk tulisan atau gambar. Dokumentasi yang berbentuk gambar misalnya seperti foto, gambar hidup, sketsa, dan lain-lain. Dalam penelitian ini dokumentasi yang ada berupa gambar dan foto yang terkait dengan Yayasan Minasa.

\section{Kritik}

Setelah mengumpulkan data langkah selanjutnya yang dilakukan adalah kitik sumber. Kritik sumber terbagi menjadi dua yaitu kritik intern dan krtitik ekstern. Kritik ektern dilakukan untuk menilai kelayakan suatu sumber. Kritik ekstern dilakukan untuk mengetahui sejauh mana keabsahan atau autentisitas sumber.

Kritik sumber yang dilakukan dengan melakukan perbandingan antara dokumen, buku, dan arsip dengan hasil kajian relevan yang terkait dengan penelitian. Diperlukan pengetahuan yang bersifat umum dalam mengetahui sifat konteks zaman. (Dien, Madjid, 2014)

\section{Interpretasi}

Dalam penulisan sejarah digunakan secara bersamaan tiga bentuk teknis dasar tulis menulis yaitu deskripsi, narasi dan analisis. Ketika sejarawan menulis sebernarnya merupakan keinginannya untuk menjelaskan (eksplanasi) sejarah, ada dua dorongan utama yang mneggerakkannya yakni mencipta ulang (recreate) dan menafsirkan (interpret). (Sjamsuddin, 2007). Dalam metode interrpretasi ini yang merupakan penafsiran terhadap data-data yang telah melalui proses seleksi dimetode kritik. Pada proses menafsirkan ini memerlukan ketelitian dari seorang penulis untuk memilah data mana yang penting untuk tema penelitian dan data mana yang tidak berkaitan dengan penelitian. Pada tahap ini penulis harus berusaha untuk mneghindari subjektivitas karena adanya perbedaan-perbedaan pandangan.

\section{Historiografi}


Historiografi atau penyajian merupakan langkah terakhir dari sebuah rangkaian metode penelitian sejarah, tahap ini merupakan proses penyusunan fakta-fakta ilmiah dari berbagai sumber yang telah diseleksi sehingga menghasilkan suatu bentuk penulisan sejarah yang bersifat kronologi atau memperhatikan urutan waktu kejadian serta menggunakan bahasa yang mudah di pahami.

\section{Tinjauan Penelitian}

Aspek geografis merupakan suatu urgensi yang penting dipahami untuk mengetahui peristiwa dalam suatu wilayah baik pada masa lalu maupun masa yang akan datang karena dengan memahami setiap wilayah akan memudahkan untuk mengetahui perubahan-perubahan yang telah terjadi pada daerah tersebut. Sebelum membahas jauh tentang Yayasan Minasa, penulis akan menuliskan dengan singkat tentang kondisi Geografis Kabupaten Luwu. Luwu merupakan salah satu kabupaten yang berada dalam wilayah administratif Provinsi Sulawesi Selatan. Kabupaten Luwu berada di bagian utara Sulawesi Selatan dengan jarak kurang lebih $400 \mathrm{~km}$ dari Makassar. (Badan Pusat Statistik Kabupaten Luwu, 2018)

Sebelumnya, Luwu adalah wilayah yang luas dan merupakan satu kesatuan dengan beberapa kabupaten yang berada di sekitarnya saat ini. Hal ini tidak terlepas dari bentuk kerajaan Luwu yang pernah eksis di masa lalu. Namun, demi mengefektifkan pemerintahan serta mengoptimalkan potensi sumber daya alam yang melimpah di jazirah Luwu, maka Kabupaten Luwu terbagi menjadi beberapa kabupaten melalui pemekaran. Wilayah Luwu saat ini terbagi dalam tiga kabupaten dan satu kota administratif yaitu, Kabupaten Luwu, Kabupaten Luwu Utara, Kabupaten Luwu Timur dan Kota Palopo. Kabupaten Luwu kini merupakan wilayah paling selatan di Tanah Luwu dengan luas wilayah 3000,25 $\mathrm{km}^{2}$ yang terdiri dari 22 kecamatan. (Badan Pusat Statistik Kabupaten Luwu, 2018)
Yayasan Minasa (Yaminas) yang merupakan tempat penampungan Ex DI/TII memiliki luas 1.000 ha, meliputi empat kecamatan yaitu Kecamatan Bua Ponrang, Kecamatan Ponrang Selatan, Kecamatan Bajo, dan Kecamatan Kamanre.

Secara astronomis, Kabupaten Luwu terletak antara $2^{\circ} 34{ }^{\prime} 45^{\prime \prime}$ - 3 30'30' LS dan

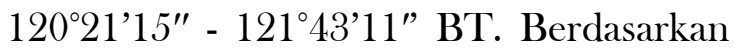
posisi geografisnya, Kabupaten Luwu dibatasi oleh Kabupaten Luwu Utara dan Kota Palopo di sebelah utara, Teluk Bone di sebelah timur, Kota Palopo dan Kabupaten Wajo di sebelah selatan, dan Kabupaten Tana Toraja dan Kabupaten Enrekang di sebelah barat.(Badan Pusat Statistik Kabupaten Luwu "Kabupaten Luwu Dalam Angka 2018)

Kabupaten Luwu terdiri dari wilayah pesisir, dataran rendah, dan dataran tinggi (pegunungan). Wilayah pesisir terdapat di sepanjang daerah yang berbatasan langsung dengan Teluk Bone. Sedangkan wilayah dataran tinggi berada pada daerah pegunungan yang ada di Luwu. Salah satu gunung yang berada di Luwu adalah Pegunungan Latimojong yang juga merupakan wilayah dari Kabupaten Enrekang dan sebagian wilayah Toraja.

Menurut data Badan Pusat Statistik Kabupaten Luwu tahun 2018, jumlah penduduk kabupaten ini sebanyak 353.277 jiwa yang terdiri atas 173.472 jiwa penduduk laki-laki dan 179.805 jiwa penduduk perempuan atau dengan rasio jenis kelamin sebesar 96 (setiap 100 jiwa penduduk wanita, terdapat 96 jiwa penduduk laki-laki). Kepadatan penduduk Kabupaten Luwu pada tahun yang sama mencapai 118 jiwa $/ \mathrm{km}^{2}$ dengan rata-rata jumlah penduduk per rumah tangga sebanyak 5 jiwa.

Penduduk yang berdomisili di Kabupaten Luwu adalah penduduk asli yang mayoritas enggan disebut sebagai Suku Bugis karena mereka merasa bahwa suku mereka adalah suku Luwu. Selebihnya, Luwu juga didiami oleh Suku Bugis dan Toraja. Sebagian kecil lainnya merupakan 
pendatang dari luar pulau seperti Jawa. Seperti mayoritas provinsi di Sulawesi Selatan, penduduk Kabupaten Luwu didominasi oleh pemeluk agama Islam.

Mayoritas penduduk kabupaten yang berada di utara Wajo ini berprofesi sebagai petani dengan memanfaatkan kesuburan hamparan alamnya. Selain bercocok tanam di sawah dan berkebun, penduduk yang berada di bagian pesisir bekerja sebagai petani tambak. Dalam kurun waktu belasan tahun terakhir, penduduk Luwu juga memanfaatkan laut untuk produksi rumput laut. Di samping itu, sejak puluhan tahun yang lalu bagang-bagang penduduk juga banyak yang berdiri kokoh di lautan. Hasil ikan laut ini dapat dilihat di beberapa tempat pelelangan ikan di Kabupaten Luwu.

\section{Hasil dan Pembahasan}

\section{Latar Belakang Yayasan Minasa}

Darul Islam merupakan gerakan separatis terbesar dan berlangsung paling lama di Sulawesi Selatan, yakni dari tahun 1950-1965. Gerakan itu dari segi cakupan wilayah, juga cukup luas yaitu meliputi sebahagian besar wilayah Sulawesi Selatan Tenggara. Bahkan dalam pembentukan negara yang diberi nama Republik Persatuan Islam Indonesia (RPII) wilayahnya meliputi Indonesia bagian Timur. Tokoh yang menjadi pimpinan utama dari gerakan itu adalah Kahar Muzakkar. (Natsir Sitonda, 2012)

Gerakan DI/TII yang telah menimbulkan banyak masalah dalam kehidupan masyarakat pada saat itu mengharuskan pemerintah yang bekerjasama dengan TNI untuk mengambil tindakan bagaimana cara memberantas gerakan DI/TII. Usaha yang dilakukan oleh pemerintah dan TNI untuk menumpas gerakan DI/TII pada umumnya dilakukan melalui dua tahap, yaitu persuasif kompromi politik dan operasi milter. Setiap tahapan yang dilakukan memiliki tujuan yang sama, namun dalam menentukan pendekatan apa saja yang digunakan tergantung pada perkembangan situasi. (Andi Asri Ashari, 2010) . Adapun tahapan yang dilakukan oleh pemerintah dan TNI dalam usaha membasmi Gerakan DI/TII adalah sebagai berikut.

\section{a. Persuasif}

Tahap persuasif yang dilakukan oleh pemerintah berkaitan dengan perubahan paham atau pengakuan terhadap ideologi dan dasar negara dari ideologi negara Islam ke Ideologi Pancasila dan Undang-undang Dasar 1945 sebagai ideologi dan dasar negara kepada anggota DI/TII, namun cara ini belum memberikan dampak yang efektif dalam pemberantasan gerakan DI/TII.

\section{b. Operasi Militer}

Operasi militer dilakukan oleh TNI untuk memberantas Gerakan DI/TII karena pasukan DI/TII yang menerapkan taktik gerilya dalam menghadapi serangan TNI. Oleh karena itu pemerintah dan TNI harus menggunakan taktik anti gerilya yang bertujuan untuk memisahkan rakyat dari musuh dengan tetap menyadari soal-soal politik, ideologi, dan sosial ekonomi. Oleh karena itu, dibentuk pertahanan total, dimana rakyat dilibatkan bersama-sama dengan TNI melakukan upaya penumpasan DI/TII. Metode penumpasan yang dilakukan oleh tentara yaitu dengan strategi bumi hangus tanpa membuka jalan perundingan, kecuali dalam bentuk seruan menyerahkan diri.

Rekonsiliasi merupakan upaya memperbaiki hubungan sosial yang akhirnya adalah perdamaian. (Gogali, 2008) Hal inilah yang kemudian terjadi antara pemerintah dengan Eks DI/TII setelah gerakan ini dinyatakan telah berakhir. Setelah gerakan DI/TII berakhir hal lain yang kemudian dihadapi oleh pemerintah adalah melakukan pembenahan diberbagai bidang. Salah satu diantaranya adalah mengadakan integrasi politik, terutama bagi mereka yang terlibat dalam gerakan DI/TII.(Andi Surianto, 2003). Pada saat itu pemerintah memberikan kesempatan kepada para Eks DI/TII untuk kembali kepangkuan Negara Republik Indonesia. Hal ini berdasarkan Surat Keputusan Ketua Gabungan V KOTI No. K/09/G. V. 
KOTI/ I965 yang berbunyi "Untuk memelihara keamanan di daerah-daerah jang bertahun-tahun lamanja diganggo oleh gerombolan pengatjau, maka setelah keamanan dipulihkan kembali, dengan tertembak matinja pemimpin gerombolan Kahar Muzakkar, pemerintah bermaksud untuk menampung para bekas gerombolan tersebut, supaja mereka kembali menjdjadi warga negara Indonesia yang baik. Hal ini juga ditegaskan oleh Eks DI/TII yang mengatakan bahwa setelah gerakan DI/TII di Kecamatan Bupon diadakan kembali pembinaan bagi mereka yang terlibat dalam gerakan DI/TII seperti mereka yang merupakan Eks DI/TII yang pada masa menjadi anggota DI/TII berprofesi sebagai guru dalam hutan kemudian dilakukan pembinaan untuk kembali menjadi guru setelah gerakan DI/TII berakhir agar mereka tetap bisa menyampaikan ilmu yang mereka miliki, selain itu juga dilakukan pembinaan terhadap beberapa orang-orang kepercayaan Kahar Muzakkar semasa hidupnya yang salah satunya adalah Abdul Azis Abdullah dengan cara mengirim mereka ke Kabupaten Pare-pare untuk dilakukan pembinaan karena pemerintah khawatir mereka masih ingin melanjutkan perjuangan Kahar Muzakkar. (Hadeyang, 2019) Setelah pemerintah merasa bahwa mereka telah terbebas dari pengaruh gerakan DI/TII maka kemudian mereka dilepaskan untuk kembali hidup bersama masyarakat. Mereka diberi kesempatan untuk kembali menjadi warga Negara Indonesia sehingga secara politik Kecamatan Bupon dapat dikendalikan oleh pemerintah Indonesia.

\section{c. Pembentukan Yayasan Minasa}

Operasi militer yang dilakukan TNI pada akhir tahun 1964 oleh pasukan Siliwangi di bawah komando Solihin berhasil memburu Kahar Muzakkar dan anak buahnya sampai ke Sulawesi Tenggara, dan hasilnya pada tanggal 3 Februari 1965 Kahar Muzakkar tertembak oleh tentara Siliwangi.

Setelah pemimpin Gerakan DI/TII yaitu Kahar Muzakkar dinyatakan telah tertembak maka para pengikut DI/TII tersebar ke berbagai derah di Sulawesi Selatan Tenggara pada masa itu. Menurut pengakuan salah satu Eks DI/TII yang mengatakan bahwa setelah tersebar kabar bahwa Kahar Muzakkar telah meninggal mereka baru berani keluar dari hutan yang terletak di Ulusalu (salah satu daerah di Kecamatn Bastem) pada tahun 1966.. Karena banyaknya Eks DI/TII yang tersebar membuat pemerintah memikirkan bagaimana cara untuk mengembalikan mereka ke dalam Negara Kesatuan Republik Indonesia.

Setelah mendengar pemerintah menyatakan bahwa komunis di Indonesia sudah tidak ada maka para aparat DI/TII yang masih dalam perjuangan mengadakan musyawarah dirumah Abdul Azis Abdullah. Hasil dari musyawarah tersebut adalah mengutus Abdul Aziz Abdullah untuk bertemu dengan beberapa jendral salah satunya Jendral Solihin dalam hal pemulihan keamanan di Sulawesi Selatan Tenggara. Setelah pertemuan tersebutl maka para Eks DI/TII memutuskan untuk keluar dari tempat mereka menyingkir dan bergabung dengan NKRI dengan misi untuk bekerjasama dengan orde baru dalam rangka Repelita. Abdul Aziz Abdullah memanggil dan mengumpulkan kembali para Eks DI/TII dengan cara menyampaikan kepada Eks DI/TII yang dari awal berada di sekitar Kecamatan Bupon untuk mengatakan kepada para Eks DI/TII yang belum mengetahui tentang Yayasan Minasa. Eks DI/TII yang keluar dan bekerjasama dengan NKRI menyatakan tidak akan melakukan pemberontakan lagi.

Karena yang bertindak untuk mengamankan seluruh eks DI/TII yang tersebar di Sulawesi Selatan Tenggara adalah Abdul Aziz Abdullah maka karena itu kemudian pemerintah memberikan balas jasa kepada Abdul Aziz Abdullah karena telah berhasil mengamankan dan membawa Eks DI/TII untuk bergabung dengan NKRI. Pemerintah kemudian menawarkan kepada Abdul Aziz Abdullah 
apakah ingin kembali ke jabatan sebelumnya yaitu sebagai anggota Polri atau menjadi pengusaha dengan memberikan modal kepada Abdul Aziz Abdullah. Tetapi dari beberapa pilihan yang diberikan semuanya ditolak karena Abdul Aziz Abdullah hanya meminta untuk diberikan tanah untuk menampung anggota Eks DI/TII. Karena Sulawesi Selatan Tenggara yang luas maka Abdul Aziz Abdullah meminta 9 kompleks dan setiap kompleks diberikan tanah seluas 1.000 ha. Setelah pemerintah memberikan 9 kompleks tersebut maka didirikanlah Yayasan Minasa pada tanggal 20 Februari 1969.

Setelah pendirian yayasan tersebut maka para Eks DI/TII yang ada di sekitar daerah Bajo, Jambu, dan Belopa yang sebelumnya memang memiliki tanah di sekitar kompleks Yayasan Minasa sebelum Yayasan tersebut didirikan tetapi mereka meninggalkan tanah tersebut saat terjadi kekacauan yang disebabkan oleh Gerakan DI/TII. Mereka kemudian ditampung di Yayasan Minasa yang diketuai oleh Abdul Aziz Abdullah. Eks DI/TII yang tersebar disemua daerah kekuasaan DI/TII pada masanya kemudian diarahkan untuk tinggal di 9 kompleks Yayasan Minasa yang tersebar di Sulawesi Selatan Tenggara untuk mulai menata kehidupan mereka kembali pasca DI/TII dan bergabung dengan NKRI.9St. Hadeyang, 2019).

Seiring dengan berjalannya waktu dari 9 kompleks Yayasan Minasa yang ada di Sulawesi Selatan Tenggara yang pada saat itu karena adanya berbagai permasalahan seperti masalah ekonomi yang masih sulit maka 8 dari 9 kompleks yayasan yang diberikan oleh pemerintah tidak bisa bertahan, dan hanya satu yang bisa bertahan yaitu Yayasan Minasa yang ada di Kabupaten Luwu.

Daerah Kabupaten Luwu dipilih menjadi salah satu lokasi untuk mendirikan Yayasan Minasa karena Luwu merupakan salah satu daerah terbesar yang memiliki pengikut DI/TII dan daerah yang merasakan dampak besar oleh Gerakan DI/TII. Yayasan Minasa ini berada di
Kabupaten Luwu, karena luas yayasan Minasa ini seluas 1.000 ha maka yayasan ini awalnya berada di Kecamatan Bupon.

Untuk memperkuat kedudukannya, Yayasan Minasa mendapat persetujuan dari beberapa pihak yaitu.

a. Gubernur Sulawesi Selatan Nomor P 3/S/16 Tanggal 1 Juni 1969.

b. Persetujuan dari Pangdam XIV Hasanuddin Nomor B.02074/1969 Tanggal 1 Juni 1969.

c. Surat Persutujuan Dewan Perwakilan Rakjat Daerah Propinsi Sulawesi Selatan No. 970/DPRD/Prop/I/1969 Tanggal 4 Juli 1969.

d. Surat Persetujuan Pengolahan Tanah di Padang Sappa dari Bupati Kepala Daerah Luwu No. Agr VI/1/4 Tanggal 26 Maret 1970.

e. Surat Keputusan Agraria Kabupaten Luwu No. A 394/9.C.RGK/71 Tanggal 14 Februari1971.

f. SK Agraria Provinsi Sulawesi Selatan Nomor PH.2/858/79 Tanggal 14 April 1979.

g. Dirjen Perkebunan Nomor TU.010/E/480 Tanggal 27 Maret 1984.

Nama Yayasan Minasa atau yang lebih dikenal masyarakat dengan sebutan YAMINAS merupakan singkatan dari Mujahidin Ansarullah artinya orang-orang yang bersungguh-sungguh dijalan Allah. Yayasan Minasa memiliki Visi "Mencipatakan Ba'datul Toyyibatun Warobbuka" yang berarti menciptakan kampung yang baik yang diridai oleh Allah Swt.. Adapun Misi Yayasan Minasa yaitu menjadikan Rukun Islam dan Rukun Iman sebagai dasar dan Al-Qur'an serta hadis sebagai pedoman. Minasa adalah masingmasing individu sebagai Mujahidin Ansarullah

Pada awal pembentukan Yayasan Minasa yang ada di Kabupaten Luwu jumlah Eks DI/TII yang ditampung berjumlah 700 orang. Tetapi seiring berjalannya waktu maka diterimalah masyarakat luar yang ingin tinggal di kompleks Yayasan minasa pada tahun 1970 dengan satu syarat yaitu syahadat yang sama 
(beragama Islam) syahadat berasal dari kata syahadah yang berarti persaksian atau pengakuan.(Abu Ahmadi, 2008). Hal ini berarti bahwa semua yang menjadi anggota Yayasan Minasa mengakui bahwa Allah adalah Tuhannya dan Nabi Muhammad adalah utusan Allah. Dengan masuknya para pendatang dari beberapa daerah ke Yayasan Minasa yang bukan merupakan Eks DI/TII ini memunculkan berbagai macam masalah

Walaupun masih eksis sampai sekarang tetapi Yayasan Minasa di Kabupaten Luwu telah melalui berbagai macam permasalahan baik itu masalah yang ditimbulkan oleh Eks DI/TII maupun masalah yang ditimbulkan oleh orang-orang pendatang di Yayasan Minasa dan beberapa masalah internal yang terjadi di Yayasan Minasa selama yayasan ini didirikan.

\section{Perkembangan Yayasan Minasa Periode 1969-1998}

Yayasan Minasa yang didirikan pada tahun 1969 pada awalnya memiliki 9 orang pengurus dan yang menjadi ketua adalah Abdul Aziz Abdulllah. Adapun susunan pengurus Yayasan Minasa periode tahun 1969-1996 sebagai berikut.

$\begin{array}{ll}\text { Ketua } & \text { : Abdul Aziz /Abdullah } \\ \text { Wakil Ketua } & \text { : Pakar Muku } \\ \text { Sekretaris } & \text { : Alimuddin } \\ \text { Bendahara } & \text { : Muliati } \\ \text { Anggota } & \text { :- Corry Van Stenus } \\ & - \text { Nahar Ghany } \\ & - \text { Abu Bakar Sakti } \\ & - \text { Arsjad Baso } \\ & - \text { Muhammad Ali Akkas }\end{array}$

Para pengurus yang terpilih ini merupakan orang-orang yang terlibat langsung dalam pendirian Yayasan Minasa dan merupakan Eks DI/TII yang telah menyerahkan diri mereka untuk menjadi warga negara Republik Indonesia.

Dalam pasal 3 akte pendirian Yayasan Minasa dituliskan azas dan tujuan yayasan, yaitu. "Jajasan ini berazaskan kekeluargaan dan kegotong rojongan berdasarkan Pantjasila dan Undang-undang Dasar 1945". Jajasan ini bertujuan. a. Menampung anggota-anggota Ex DI/TII dengan maksud membantu pemerintah dalam usahanja menjelanggarakan/melaksanakan rentjana pembangunan negara dalam arti seluas-luasnja.

b. Membina kesatuan dan kerukunan serta kesedjahteraan daripada anggotanja, demi kelanjutan hidup dan penghidupan di bidang sosial, ekonomi, kebudajaan dan pendidikan.

c. Sebagai wadah perdjoangan bagi anggota-anggotanja untuk mengabdi pada Agama, Bangsa, dan Negara Republik Indonesia berdasarkan Pantjasila dan Undang-undang Dasar 1945.

Perkembangan Yayasan Minasa pada masa awal pendirian yayasan yaitu tahun 1969 sampai akhir kepengurusan Abdul Aziz Abdullah ditahun 1998 dapat dilihat sebagai berikut.

\section{a. Bidang Sosial Ekonomi}

Keadaan para Eks DI/TII di Kabupaten Luwu khusunya di Kecamatan Bupon pasca berakhirnya gerakan DI/TII masih mempertahankan prinsip-prinsip dan perjuangan Kahar Muzakkar walaupun pemimpin mereka telah meninggal. Dari sinilah terbentuk solidaritas tersendiri bagi para Eks DI/TII apalagi setelah mereka tinggal di Yayasan Minasa. Untuk memperkuat determinasi perjuangan mereka ditempuh dengan dua cara, yakni memberikan kesempatan kepada Eks DI/TII untuk menduduki jabatan penting dalam pemerintahan dan memperjuangkan kemaslahatan masyarakat. Perjuangan dengan jalur kultural, yakni dengan membangun kehidupan sosial budaya dan keagamaan masyarakat. Melalui kedua perjuangan tersebut, maka terdapat sinkronisasi perjuangan Kahar Muzakkar dalam wujud generasi kedua. Walaupun mereka melanjutkan perjuangan Kahar Muzakkar, tetapi mereka menempuh jalan yang berbeda yaitu bukan lagi dengan peperangan melainkan melalui jalur dakwah yang jauh dari peperangan dan kekerasan. 
Karena lahan di Yayasan Minasa yang luas dan masih banyak yang belum dikelola maka pengurus yayasan sepakat untuk menerima orang-orang selain Eks DI/TII untuk tinggal di Yayasan Minasa dengan satu syarat yaitu mereka harus mengucapkan dua kalimat syahadat. Setelah kesepakatan tersebut maka pada tahun 1970 orang-orang dari luar daerah Kabupaten Luwu mulai berdatangan dan kemudian tinggal di Yayasan Minasa untuk mencari pekerjaan dengan cara bertani dan berkebun. Karena kondisi tanah di Yayasan Minasa yang subur itulah kemudian semakin menarik orang-orang untuk datang di Yayasan Minasa. dengan ketentuan mereka hanya memajak tanah milik eks DI/TII dengan ketentuan membagi hasil tetapi lama kelamaan mengambil tanah secara sepihak.

Di bawah kepemimpinan Abdul Aziz Abdullah dengan segala daya dan upaya untuk mendapatkan dana (penanaman modal) baik berupa PMDN (Penanaman Modal Dalam Negeri) atau PMA (Penanaman Modal Asing) dengan tujuan untuk mendapatkan HGU (Hak Guna Usaha), namun belum tercapai maka muncul masalah baru yaitu pemekaran wilayah desa di beberapa kecamatan di tanah Yayasan Minasa terbagi dalam beberapa wilayah pemekaran diantaranya Kecamatan Bajo, Kecamatan Kamanre, dan Kecamatan Ponrang Selatan. Dengan pemekaran wilayah desa tersebut, pimpinana Yayasan Minasa tidak berkeberatan walaupun pada awalnya Yayasan Minasa berada di Kecamatan Bua Ponrang Desa Noling. Maka untuk mencegah munculnya hal-hal yang tidak diinginkan di antara masyarakat maka pimpinan Yayasan Minasa mengambil satu kebijakan yaitu menerbitkan surat untuk anggota yang mengolah tanah di dalam areal Yayasan Minasa yakni SPHT (Surat Pelimpahan Hak Tanah) dengan tujuan sebagai berikut.

a. Tanah olahan anggota adalah milik anggota tersebut. b. Untuk mendapatkan sertifikat pajak dari pemerintah

c. Dan lain-lain.

b. Bidang Pendidikan

Pendidikan merupakan aspek yang sangat penting dalam suatu negara untuk mencerdaskan kehidupan bangsanya. Pendidikan di Yayasan Minasa dimulai sejak awal pendirian Yayasan Minasa walaupun pendidikannya belum secara formal. Pendidikan pada masa itu hanya dilakukan oleh orang tua kepada anaknya dengan mengajarkan tentang agama. Pendidikan secara formal baru ada di Yayasan Minasa pada tahun 1972 dengan didirikannya Pesantren Istiqamah Cabang Salu Makarra. Hal ini tidak terlepas dari kebiasaan para Eks DI/TII saat mereka masih menjadi anggota DI/TII karena Kahar Muzakkar semasa hidupnya memilki ketekunan dalam membaca buku, walaupun pada masa itu kahar Muzakkar dan para pengikutnya di bawah bayangbayang operasi militer untuk memberantas gerakan DI/TII tetapi mereka tetap rajin membaca buku dan bersekolah. Karena pada masa DI/TII pendidikan merupakan hal yang sangat penting terutama pendidikan tentang agama. Pasca gerakan DI/TII ada beberapa dari Eks DI/TII yang memiliki keahlian dalam bidang pendidikan diberikan SPG kilat oleh pemerintah, mereka dibekali agar bisa mengajar di sekolah.

Pendidikan di Yayasan Minasa bercorak pendidikan Islam, hal ini dapat dilihat dari ketiga pesantren yang didirikan di Yayasan Minasa. Di Yayasan Minasa ini telah didirikan beberapa pesantren untuk keberlangsungan pendidikan para anak cucu eks DI/TII. Pada masa kepemimpinan Abdul Aziz Abdullah didirikan 3 pesantren, yaitu Pesantren Istiqamah Cabang Salu Makarra, Pesantren Istiqamah cabang Yaminas Noling, Pesantren Istiqamah cabang Yaminas Loppe.

\section{c. Bidang Keagamaan}


Kehidupan masyarakat Yayasan Minasa dalam bidang keagamaan tetap mempertahankan dan memegang teguh prinsip-prinsip perjuangan untuk taat beragama. Kehidupan masyarakat Yayasan Minasa yang tetap taat menjalankan syariatsyariat Islam dan menjadi panutan bagi masyarakat lain. Ajaran islam yang diajarkan di Yayasan Minasa adalah ajaran islam yang tidak masuk dalam aliran-aliran agama Islam yang banyak tersebar seperti sekarang ini. Dalam proses interaksi sosial dengan masyarakat lain mereka tetap berinterkasi satu sama lain, saling menghormati dan saling membantu. Pada tahun 1972 didirikan Majelis Ta’lim agar bisa lebih mempererat hubungan silaturahmi dan juga merupaka upaya untuk mengembangkan ajaran Islam. Majelis Ta'lim ini tidak hanya melakukan kegiatakegiatan beragama di lingkungan kompleks Yayasan Minasa saja, melainkan juga melakukan kegiatan-kegiatan di luar kompleks Yayasan Minasa.

\section{d. Perkembangan Yayasan Minasa Periode 1996-2018}

Setelah meninggalnya Abdul Abdul Aziz Abdullah pada tahun 1998 maka jabatan Ketua Umum Yayasan Minasa mengalami kekosongan. Akan tetapi urusan internal Yayasan Minasa teap terkendali dengan baik di bawah kepengurusan dewan komisi, wakil ketua umum, dan ketua-ketua kelompok, yang ditetapkan oleh Abdul Aziz Abdullah sebagai pengemban amanah dengan surat No.Ist-CH/96 yang menetapkan St. Hadeyang sebagai wakil ketua umum Yayasan Minasa. Pada tanggal 30 April 2002 St. Hadeyang diangkat menjadi ketua Umum Yayasan Minasa.

\section{1) Perkembangan dalam Bidang Sosial Ekonomi}

Setelah pemilihan pegurus baru Yayasan Minasa yang dipilih melalui musyawarah yang dilakukan pada tanggal 30 April 2002 maka para mengurus yang terpilih mulai melakukan tugasnya masingmasing sesuai dengan tugas yang telah diberikan. Kehidupan sosial masyarakat mulai mengalami perubahan. Peraturan- peraturan yang telah ditetapkan sebelum menjadi anggota Yayasan Minasa mulai dilanggar oleh beberapa masyarakat, seperti berjudi, minum arak dan berzinah. Hal ini disebabkan karna para Eks DI/TII sudah banyak yang meninggal dunia sehingga yang ada tinggal generasi mereka yang mulai kurang mendalami ilmu agama. Penyebab lainnya adalah mulai masuknya pengaruh dari luar ke dalam lingkungan Yayasan Minasa. Tetapi selain daripada itu masih banyak masyarakat Yayasan Minasa yang masih tetap memegang teguh peraturanperaturan yang ada di Yayasan Minasa.

Dengan beberapa sumber mata pencaharian masyarakat Yayasan Minasa sehingga mendukung untuk dapat menyekolahkan anak-anak mereka ke perguruan tinggi negeri maupun swasta yang ada di Sulawesi Selatan dan di luar pulau Sulawesi. Tetapi salah satu yang menjadi masalah adalah para generasi muda Yayasan Minasa yang telah menyelesaikan pendidikannya di perguruan tinggi banyak yang memilih untuk mencari pekerjaan di luar Yayasan Minasa, hal ini tidak sesuai dengan harapan para pimpinan Yayasan Minasa yang mengharapkan generasi muda tersebut kembali ke Yayasan Minasa untuk membangun daerah mereka sendiri. Sampai tahun 2018 masyarakat Yayasan Minasa memiliki profesi yang berbeda-beda seperti petani, pekebun, pedagang, wiraswasta dan Pegawai Negeri Sipil.

\section{2) Bidang Pendidikan}

Pada masa kepemimpinan St. Hadeyang kondisi pendidikan di Yayasan Minasa terus mengalami perkembangan. Ada satu tambahan pesantren yang baru didirikan pada tahun 2015 yaitu Pesantren Tahfidzul Qur'an Sububassalam Yaminas yang merupakan salah satu cita-cita dari bapak Abdul Azis Abdullah. Dengan didirkannya pesantren tahfids ini lebih memudahkan generasi-generasi muda yang ada di Yayasan Minasa yang ingin lebih memperdalam ilmu agama dan ingin mengafal Al-Qur'an.

Pada perkembangannya pesantrenpesantren di Yayasan Minasa mengalami 
perkembangan yang baik, baik itu dari segi tenaga pengajar maupun fasilitas-fasilitas yang ada. Dari segi kurikulum pendidikan Yayasan Minasa tetap mengikuti kurikulum yang berlaku di Indonesia. Yang membedakan dengan sekolah-sekolah umum hanyalah pelajaran tentang agama yang lebih dikhususkan, berbeda dengan sekolah-sekolah umum lainnya.

Yayasan Minasa juga telah memberikan pengaruh yang cukup besar dalam bidang pendidikan. Dengan adanya pesantrenpesantren yang didirikan di Yayasan Minasa telah memberikan pengaruh yang cukup besar khususnya bagi anak-anak yang ada di kompleks Yayasan Minasa yang ingin melanjutkan pendidikan. Sebelum didirikannya Pesantren-pesantren di Yayasan Minasa banyak anak-anak yang tidak bersekolah karena jarak tempat tinggal yang sangat jauh dari sekolah yang ada pada masa itu. Setelah didirikannya pesantren-pesantren tersebut telah memudahkan para anak-anak yang ada di Yayasan Minasa untuk bersekolah dan melanjutkan pendidikan ke tingkat yang lebih tinggi.

Siswa-siswa yang ada di pesantrenpesantren Yayasan Minasa juga berperan dalam pengembangan dakwah di wilayah Kabupaten Luwu. Pada saat bulan Ramadhan maka mereka akan diutus untuk melakukan ceramah ke masjid-mesjid yang ada di Kabupaten Luwu. Kemudian setelah didirikannya pesantren. Pesantren Tahfidzul Qur'an Sububassalam Yaminas maka Yayasan Minasa semakin ikut berperan dalam pendidikan Islam di Luwu. Sesuai dengan cita-cita para pendiri Yayasan Minasa yang ingin menjadikan ajaran Islam sebagai dasar dalam kehidupan sehari-hari masyarakat Islam itu sendiri karena pada kenyataanya masih banyak orang-orang yang beragama Islam tapi melenceng dari ajaran Islam itu sendiri.

\section{3) Bidang Keagamaan}

Kehidupan beragama masyarakat Yayasan Minasa telah mengalami banyak perubahan jika dibandingkan dengan kondisi keagamaan Yayasan Minasa pada masa awal pendirian yayasan. Mesjid yang dulunya selalu penuh dengan jamaah sholat lima waktu sekarang mulai mengalami perubahan dimana masyarakat mulai banyak yang tidak melaksanakan shalat di masjid, hal ini terjadi karena banyak masyarakat yang tidak memperhatikan kewajiban mereka sebagai umat Islam dan sibuk dengan pekerjaan mereka. Begitupun dengan pengajian rutin yang dilakukan oleh Majelis Ta'lim Subulassalam walaupun masih terus dilakukan tetapi yang ikut hadir sudah mulai berkurang.

Kebiasaan yang tidak pernah ditinggalkan oleh masyarakat Yayasan Minasa dari awal sampai sekarang adalah penggunaan kain tabir/hijab disetiap acara pernikahan yang dilaksanakan dalam kompleks Yayasan Minasa. Kain tabir/hijab ini digunakan untuk memisahkan antara tamu undangan laki-laki dan perempuan. Hal ini merupakan ciri khas setiap acara pengantin yang dilakukan di Yayasan Minasa. Selain itu mayarakat Yayasan Minasa juga memiliki kewajiban untuk membayar infaq dari hasil perkebunan mereka kepada yayasan, hasil dari pengumpulan infaq digunakan untuk keperluan yayasan seperti pembangunan ruang kelas pesantren, pembangunan dan perenovasian $\mathrm{masjid} / \mathrm{mushalla}$.

\section{E. Kesimpulan}

Latar belakang didirikannya Yayasan Minasa adalah sebagai imbalan jasa kepada Abdul Aziz Abdullah karena bertindak untuk mengamankan Eks DI/TII yang tersebar di Sulawesi Selatan Tenggara maka dari itulah kemudian pemerintah memberikan balas jasa kepada Abdul Aziz Abdullah karena telah berhasil mengamankan dan membawa Eks DI/TII untuk bergabung dengan NKRI. Tujuan utama didirkannya Yayasan Minasa adalah untuk menampung anggota-anggota Ex DI/TII dengan maksud membantu pemerintah dalam usaha menyelanggarakan/melaksanakan rencana 
pembangunan negara dalam arti seluasluasnya. Seiring dengan berjalannya waktu dari 9 kompleks Yayasan Minasa yang ada di Sulawesi Selatan Tenggara yang pada saat itu karena adanya berbagai permasalahan seperti masalah ekonomi yang masih sulit maka 8 dari 9 kompleks yayasan yang diberikan oleh pemerintah tidak bisa bertahan, dan hanya satu yang bisa bertahan yaitu Yayasan Minasa yang ada di Kabupaten Luwu.

Dalam perkembangannya selama kurang lebih 49 tahun Yayasan Minasa telah dipimpin oleh dua ketua yaitu Abdul Aziz Abdulllah yang memimpin dari tahun 1969-1999, dan St. Hadeyang yang memimpin dari tahun 2002-sekarang. Kehidupan sosial ekonomi masyarakat Yayasan Minasa berlangsung dengan baik walaupun telah mengalami perubahan jika dibandingkan dari awal pendirian Yayaysan Minasa, masyarakat Yayasan Minasa berprofesi sebagai petani, pekebun, peternak, PNS, dan wiraswasta. Pendidikan di Yayasan Minasa bercorak Islam dan telah memiliki pesantren Tahfidzul Qur'an Sububassalam Yaminas serta 3 pesantren yang dimulai dari tingkatan Raudhatul Anhal, Madrasah Ibtidaiyah, Madrasah Tsanawiyah, dan Madrasah Aliyah. Kehidupan beragama masyarakat Yayasan Minasa pada awalnya masih memegang teguh ajaran-ajaran yang telag ditanamkan oleh Kahar Muzakkar dan mentaati aturanaturan yang telah ditetapkan namun dalam perkembangannya sudah banyak masyarakat yang telah melanggar hal tersebut.

\section{F. Daftar Pustaka}

Andi Asri Ashari, S., 2010. Pemberontakan DI/TII di Kabupaten Soppeng (1950-1965). Makassar: Fakultas Ilmu Budaya Universitas Hasanuddin.

Badan Pusat Statistik Kabupaten Luwu, 2018. Kabupaten Luwu Dalam Angka 2018.
Borahima, A., 2010. Kedudukan Yayasan di Indonesia. Jakarta: Kencana Prenada Grup.

Dien, Madjid, M., 2014. Ilmu Sejarah Sebuah Pengantar. Jakarta: Kencana

Gogali, L., 2008. Rekonsiliasi Ingatan. Yogyakarta: Galangpress.

Hadeyang, S., 2019. Eks DI/TII.

Jande, H., 17 Maret 2019. Eks DI/TII. s.l.:s.n.

Kutha Ratna, N., 2010. Metode Penelitian Kajian Budaya dan Ilmu Sosial Humaniora Pada Umumnya. Yogyakarta: Pustaka Pelajar.

Natsir Sitonda, M., 2012. Integrasi Gerilya. Makassar: Yayasan Pendidikan Mohammad Natsir.

Prasetya, R., 2014. Yayasan Dalam Teori dan Praktik. jakarta: Sinar Grafika.

Sjamsuddin, H., 2007. Metodologi Sejarah. Yogyakarta: Ombak.

Supranomo, g., 2008. Hukum Yayasan di indonesia. jakarta: rineka cipta. 